\title{
Introduction: Shakespeare and 'the personal story'
}

\author{
Katherine Scheil and Graham Holderness
}

It seems to be a kind of respect due to the memory of excellent men, especially of those whom their wit and learning have made famous, to deliver some account of themselves, as well as their works, to Posterity. For this reason, how fond do we see some people of discovering any little personal story of the great men of Antiquity, their families, the common accidents of their lives, and even their shape, make, and features have been the subject of critical enquiries. How trifling soever this Curiosity may seem to be, it is certainly very natural; and we are hardly satisfy'd with an account of any remarkable person, 'till we have heard him describ'd even to the very cloaths he wears. (Nicholas Rowe, 1709)

Thus Shakespeare biography was born. Out of the 'respect due to the memory of excellent men' arises a 'Curiosity' regarding the 'personal story'. Published in 1709, Rowe's Account celebrates its tercentenary this year. Since then, hundreds of biographies and imaginative works have appeared, from a single year in Shakespeare's life (1599) to a novelization of Shakespeare's dog. ${ }^{1}$

From Rowe to Shapiro, innumerable Lives of Shakespeare have been written, by scholars and academics, by professional novelists and biographers, and by creative writers. All are in quest of the same 'personal story', but they tell it in different ways. Scholars typically approach the life on the basis of an extensive knowledge of the actual textual works and their critical literature; of Renaissance history, local and national; of the Tudor and Stuart theatre; and of Shakespeare's many afterlives, in drama, criticism, film, and the broader culture. The works precede the life, and it is the works that speak of the man. Professional biographers have a more difficult task, since the confessional material that is their stock-in-trade is virtually absent: there are no letters, diaries, or directly reported conversations; no testimonies from family, friends, and neighbours about 'the common accidents' of Shakespeare's life. Biographers depend on the same 
materials as scholars, but typically seek to supplement these by what scholarship would regard as unlicensed imaginative speculation. Creative writers give free reign to the imagination, and produce, out of the raw biographical facts and the mysterious connections between life and works, overtly fictional biographies that nonetheless demonstrate a surprising plausibility, and exercise a curious compulsion over the popular imagination. Here the 'personal story' tends to align with the impersonal patterns of myth and legend.

Scholar, biographer, and creative writer all seek to define the individuality of Shakespeare as author, and as child, young man, lover, husband, father, businessman, and so forth. But all are constrained by a lack of personal data. We know when and where Shakespeare was baptized, who his parents and siblings were, whom he married and when, how many children he had and when one of them died. We know about his success as a writer and much about his professional career. We know about his property dealings and the contents of his will. But we do not know exactly when he was born; where, when, or even if he went to school; what he was like as a child; if his family was very poor, or reasonably well off. We do not know if he worked for his father as a young man, or did something else; what happened to him in the 'lost years' 1585-1592; how he became an actor and writer; if he stayed in London to keep away from his family in Stratford. We do not know exactly when he died, or what he died from. We don't know for sure if he had to get married; if he loved his wife; if he ever lived anywhere but Stratford and London; if he had relations with other women, or men; if he was religious, and if so of what persuasion; if he loved his children; how much he cared about his writing. We know nothing for certain about the relation between his writing and his life. We do not know what he believed in; what he cared about; what he thought about anything at all.

Shakespeare scholars since Edmund Malone have tried to construct a biography based on the historical evidence, and to explore links between the man and his works. There is of course massively more information about the latter than the former, but the two are notoriously difficult to connect. While Shakespeare the public man is ubiquitously visible, Shakespeare the private man remains largely mysterious and unfathomable.

Notwithstanding, in the last few years there has been an explosion of interest in the life of Shakespeare: according to Anne Barton's count, at least one formal biography of Shakespeare has appeared 
every year since 1996. Popular interest in the Bard's life, based on his massive literary achievement, but focusing on the more romantic or salacious possibilities of his personal life, also shows no sign of abating. Since Rowe collected stories about Shakespeare's youthful misdemeanours, there has been an inexhaustible public appetite for such Shakespearean legend, culminating in the hugely successful 1998 film, Tom Stoppard and Marc Norman's Oscar-winning Shakespeare in Love, which explains Romeo and Juliet as the side effect of a love affair. From this popular mythology the lay observer could be forgiven for assuming as fact that Shakespeare had to get married and hated his wife, was gay lover to the Earl of Southampton, loved a Dark Lady who was probably a prostitute, and died of syphilis. None of this colourful material has any firm basis in history, but all of it has achieved 'a hold on popular affection that no argument can weaken'. ${ }^{2}$

The last decade or so has been a particularly fruitful period for Shakespearean biographies; interest in both popular and academic biographies continues to grow; ${ }^{4}$ and imaginative works about Shakespeare's life have flourished, in the form of novels, poems, plays, films, radio and television drama, and artworks, including Robert Nye's epistolary novel Mrs. Shakespeare, Grace Tiffany's novels Will and My Father Had a Daughter, Peter Whelan's play The Herbal Bed, Vern Thiessen's play Shakespeare's Will, William Boyd's film Waste of Shame, and Shakespeare in Love.

Capitalizing on the analytical potential in this growing body of work, the essays in this issue were initially written for a seminar at the 2008 International Shakespeare Conference in Stratford, focusing on the various ways in which Shakespeare's life has been constructed, appropriated, and refigured in the last 300 years. Contributors consider what is at stake in the many 'texts' of Shakespeare's life in various historical periods, cultures, and contexts, and how Shakespearean biography relates to other cultural, literary, and political climates. The essays in this issue take into account aspects of Shakespeare's life and the multifarious ways his afterlife has been configured in different periods, locales, and venues, from nineteenth-century Germany to the twenty-first century stage.

The lasting sense of authority conferred by Shakespeare long after his death in 1616 occupies two contributors. Paul Franssen traces versions of Shakespeare's ghost, beginning on the late seventeenthcentury stage and extending to Continental Europe, and the changing 
states of authority in relation to bardolatry and the right to stage, adapt, and tamper with the works through the twentieth century. Reiko Oya examines the ways various imaginary relationships behind the Sonnets haunt late nineteenth-century England, looking at how biographical interpretations of the Sonnets influenced the relationships between Oscar Wilde, Alfred Lord Douglas, Frank Harris, and George Bernard Shaw.

Just as the life materials of Shakespeare himself have provided a seemingly endless proliferation of biographical and fictional works, so too have the lives of those connected to Shakespeare. Robert Sawyer looks at how the relationship (and rivalry) between Shakespeare and Christopher Marlowe has been refigured over the last hundred years according to various critical and political climates, and how Marlowe has served a particular purpose in constructing versions of 'Shakespeare'. Shakespeare's wife Anne Hathaway does not escape the fictionalizing fervour; Katherine Scheil offers a paradigm for how Hathaway's life has been imagined along the lines of domesticity and sexuality, inspired by the problematic 'second best bed' phrase from Shakespeare's will.

One of the key aspects of the personal story that has recently assumed new importance due to a resurgence of the 'Catholic Shakespeare' question, is religion. The topic of Shakespeare and religion is taken up by two contributors, in terms of Shakespeare's own religious background, and later uses of his religious views on the Continent. Sonja Fielitz discusses the role Jesuits may have played as cultural mediators for Catholicism in early modern England, relating this to both Shakespeare and to the stage. Wolfgang Weiss shows that the question of Shakespeare and religion was not confined to the early modern period, but rather has resonated with later readers and other nationalities, particularly in the ways Shakespeare has been constructed as Protestant or Catholic in nineteenth-century Germany.

In addition to the six essays on topics related to Shakespeare biography, this issue also includes invited essays by Stanley Wells and Park Honan, considering the question of why Shakespearean biography has experienced so much recent interest in both popular and academic venues, and reflecting on the process of life writing and the implications for biographical studies.

Park Honan, the author of the well-respected biography Shakespeare: A Life (Oxford, 1999), posits several factors affecting the reception of literary biography, and the relationship between social 
history and life writing. The boundaries between biography and fiction seem a particularly fruitful area for analysis; as Honan points out in his piece, biography should be 'able to depict as much about life as works of fiction can'. Honan acknowledges that 'no rules govern the nature of biographical writing of course, so one makes up one's own rules'. With Shakespeare, the relationship between the literary works and the life is perhaps the central structural question for biographers to determine in crafting a life of Shakespeare. While Honan focuses mainly on the life details, he describes a 'romantic crush' on Shakespeare's plays that kept them in his mind while writing about Shakespeare's growth and development.

In his cleverly titled essay 'What Was He Really Like?', Stanley Wells, editor of The Oxford Shakespeare and author of the 'life and works' study Shakespeare: For All Time, expresses his interest more in Shakespeare's 'personality' than in the 'externals of his life', pointing out that 'personal characteristics' were of great interest to Shakespeare himself. Although he confesses that he has not 'committed a full-length biography', Wells ponders the type of biography he would like to both read and to write, one which would show the 'connections between his day-to-day life and his imaginative achievements'. Given the solid audience base for biographies of Shakespeare, there seems to be plenty of room for Wells, and others, to contribute to this ever-increasing body of work.

Finally, in honour of the three-hundredth anniversary of Rowe's Account, Graham Holderness offers a 'second edition' which incorporates later anecdotes about Shakespeare and affirms the vitality and possibilities inherent in the life and afterlife of Shakespeare.

\section{Notes}

1. Nicholas Rowe, Some Account of the Life of Mr. William Shakespear (London, 1709), i-ii; James Shapiro, 1599: A Year in the Life of William Shakespeare (New York: Harper Collins, 2005); Leon Rooke, Shakespeare's Dog (Toronto: General Publishing Company, 1981).

2. Alice Fairfax-Lucy, Charlecote and the Lucys (Oxford: Oxford University Press, 1958), 5.

3. Anne Barton, 'The One and Only,' The New York Review of Books 53.8 (11 May 2006). As Barbara Everett has recently remarked 'of Shakespearean biography in particular there has been a flood over the last few decades, good, bad and indifferent.' TLS 17 August 2007. 